UDK 614.8-055.2

https://doi.org/10.18485/fb_ic4hs.2018.25

\title{
DISASTER RISK REDUCTION - GENDER ASPECTS ${ }^{1}$
}

\author{
Zorica MRŠEVIĆ*, Svetlana JANKOVIĆ ${ }^{* *}$
}

\begin{abstract}
The subject of this paper is the gender aspect of the disaster risk reduction concept. A natural phenomenon in itself is not a disaster, but it becomes when it strikes a vulnerable community, a group or individuals without proper defence who have no ability to resist or to repair its negative effects. It causes material damage and human losses, possible interruption of the economic and social functioning of the community. The threat of disasters is a matter of overall human security and implies bringing into question the safety of life, housing and economy, food, water, energy, health, and environmental safety. The aim of the paper is to point out that disasters are not a 'natural' inevitability, since they are the result of natural risk factors and human vulnerability, in which gender-based inequalities are a constitutive component. Consequently, disaster risk reduction processes that include prevention, mitigation and preparedness for response in all phases should have a necessary gender perspective, with the aim of increasing disaster resilience. Such an approach is based on the knowledge of the risk management, capacity building and the use of information and communications technology, as well as the analysis of existing gender relations and the need to change unsafe discriminatory practices in the field. Namely, the opportunities available to women and men in fact are not the same even in 'normal' circumstances, not to mention the emergencies. There is a gender division of jobs, unequal access to material and non-material resources, lesser participation of women in decisionmaking at political and private levels, women's exposure to gender-based violence and various forms of discrimination. The conclusion is that building resistance to disasters, empowering women and community development necessarily represent elements of unique, but not separate, efforts.
\end{abstract}

Keywords: disasters, women, gender relations, poverty, disaster risk reduction

1 This text was created as part of the project of the Institute for Social Sciences in Belgrade: "Social Transformations in the Process of European Integration - Multidisciplinary Approach", funded by the Ministry of Education, Science and Technological Development, no. III 47010.

* PhD, Senior Research Fellow, Institute of Social Sciences, Belgrade, zmrsevic@idn.org.rs

${ }^{* *}$ MA, Lieutenant Colonel, PhD candidate, University of Belgrade Faculty of Security Studies, svetlana.jankovic.cacak@gmail.com 


\section{INTRODUCTION}

Human and property exposure to catastrophes2 (UNISRDE, 2009) is increasing faster than their vulnerability is being reduced throughout the world. This creates new risks and gradually increases losses caused by catastrophes, with significant economic, social, health, cultural and environmental impacts in the short, medium and long term, especially at the local community level. Disasters can occur suddenly (fast start: typhoons, earthquakes, volcanoes) or gradually (slow start: climate change, drought, desertification, gradual melting of polar glaciers). They affect millions of people (Mršević and Janković, 2018). Over the last decade, they have affected nearly 2 billion people and caused damage estimated at \$ 1.7 trillion. In addition, from 2008 to 2012, 144 million people were displaced due to disasters. Disasters, most of which are worsened by climate change and continually increasing in frequency and intensity, substantially inhibit progress towards sustainable development.

Constant rise in disaster risks, including the increased exposure of people and property, combined with previous disaster experiences, points to the need to further strengthen disaster response preparedness, to undertake event prediction actions, to integrate disaster risk reduction in response preparation, and to ensure that there are capacities for effective response and recovery at all levels.

\section{IMPACT OF DISASTERS ON WOMEN - KINDS AND EXAMPLES}

Only at the end of the twentieth and the beginning of the twenty-first century, did the world become aware of considerably higher number of female victims compared to male victims due to catastrophes. First of all, there is a direct and the most visible consequence of disasters in the form of a disproportionately greater loss of women's lives. Moreover, humanitarian organisations point out that the consequences of the same catastrophic events that occur later on, such as illness, hunger, homelessness, property loss, unemployment, gender-based violence, disability, etc. also affect more often affect women than men.

These mentioned examples are not the only ones, but rather chosen as to paradigmatically illustrate the female disaster vulnerability.

The devastating cyclone, which hit Bangladesh on 2 August 1991, caused the death of 135 to 145 thousand people (History.com Editors, 2009). It was then observed that far more women were killed, not only because they were physically weaker, but because of the religious tradition that supported male domination and restricted mobility of women (Begum, 1993: 35 ). In the population aged 20 to 44, a total of 71 women and 15 men were killed per thousand people. The example of Bangladesh became paradigmatic for finding that women were the first ones affected by disasters, and that they were hit harder (Oxfam-GB, 2011). In Bangladesh, on 15 November 2007, cyclone Sidr caused, according to the initial estimates, about 4,000 casualties, so that humanitarian organisations later published the information

${ }^{2}$ Disasters are natural phenomena that seriously impair the safety and functioning of society, including widespread human, economic or environmental damage, which exceeds the ability of an endangered society to defend itself by its own forces and remedy the consequences with its own resources. 
about 10,000 victims and millions of people left without their homes (Mathbor, 2016), highlighting particularly the vulnerability of female population ${ }^{3}$ (UNDP, 2010).

In an earthquake that hit Kashmir in mid-November 2005, 73,318 persons were killed or missing, according to official data, but international estimates were that the victims totalled 87 thousand. Women were the most numerous victims and were killed due to the strict custom of 'purdah', according to which women are confined to moving only within their homes, where most of them died of fear of violating the ban on moving freely in public. In places where the demand for purdah was not so strict, women managed to escape from being overcrowded (Parker, Hamilton and Halvorson, 2007).

In Peru, a warning about the arrival of El Ninja in February 2003 was sent only to fishermen, and as women did not engage in fishing, they did not have this information at all. This directly caused enormous damage that could have been avoided if women had known in advance that existing food supplies should have been saved from storms (UNISDR, UNDP and IUCN, 2009: 24, 44).

The world public faced a brutal fact of the prevailing number of women victims (Jungehülsing, 2012) in the case of the Asian tsunami of 2004, when, in Indonesia and Sri Lanka, the proportion of survivors was one woman per four men, or $75 \%$ of women victims, while in some Indian regions women accounted for $80 \%$ of victims. The International Humanitarian Relief Agency reported that there were four times more female victims than male victims because of social customs that prevented women from moving freely without men (BBC, 2005).

On 2 May 2008, 138,000 people were victims of Cyclone Nargis according to the official reports. There certainly should be added 55,000 missing as well as an unknown number of victims in the 'second wave' that included subsequent victims of hunger, violence and epidemics as a result of cyclonic destruction. According to UNICEF's first estimates, more than half of the victims of Nargis were women and children, while it was pointed out later that women suffered double more than men (Singh, 2012).

\section{CAUSES OF WOMEN'S HIGHER VULNERABILITY}

UNDP Disaster Risk Reduction Advisor (Cecilia Aipira), says that women and girls are most affected by natural disasters, but that there is no solid data to show in what way. "As a consequence, they remain largely invisible in assistance and development programmes," she said when presenting the newly opened Centre for Gender and Disaster at the University College in March 2018. (UNDP, 2018). Lack of data on the impact of natural disasters and conflicts on women disables all provisions and plans of assistance and recovery from the negative consequences of such disasters. ${ }^{4}$ Unfortunately, the recent

${ }^{3}$ In November 2007, Cyclone Sidr tore through the coast of Bangladesh, killing almost 4,000 people, leaving millions homeless and destroying the livestock, crops, farming equipment and fishing boats essential for people's livelihoods. Bangladesh - Rebuilding Cyclone Sidr Victims.

4 A survey in Chad carried out within the Building Resilience and Adaptation to Climate Extremes and Disasters (Braced) programme has shown that discrimination and violence prevent women from accessing financial and medical assistance in times of crisis. No statistics are gender disaggregated. In disaster-prone areas, such as Nepal, India or Haiti, women do not have any information about disasters, how they should behave, and whom they should address in case disasters happen. 
events have shown that it is similar with other 'developed' areas, for example, during recent disasters in Greece, Japan and California.

Given that the extent of disasters is partly under the influence of political, economic and socio-cultural context, the introduction of a gender component into policies and measures to combat disasters begins with the identification of how women and men are positioned in one society (Centre for Disaster Preparedness, 2010). Limited access to women's economic, social and human resources and their reduced decision-making power both at home and in the political sphere reduce their capacity to implement adaptation and protection measures.

They face different levels of risk and are in various ways vulnerable to risky situations and in various ways deal with the consequences of disasters, which is caused by gender-based political, cultural and socio-economic differences and inequalities that persist throughout the world. Compared to men, women are poorer, have fewer opportunities to gain and develop entrepreneurial skills, weaker access to financial resources such as loans, savings or pensions, fewer opportunities to buy or own land, if they are generally paid less - their earned income is more irregular. When floods occur, only wealthy people are able to move to safer places or send their supplies to safe locations. A typical, low paid rural woman living in a poor community has no opportunity to move to safer housing, and disasters as flood / fire / earthquake usually cause loss of everything, including all her supplies, movable and immovable property (Centre for Disaster Preparedness, 2010.b).

Poverty is the key element that determines vulnerability of individuals and countries. Globally, poverty is largely female, $70 \%$ of the world's poor are women ${ }^{5}$ (Making Disaster Risk Reduction Gender-Sensitive, 2009: 133), which means that women make up the majority of those who live and work in insecure places and in uncertain conditions. Although both sexes are exposed to physical vulnerabilities during natural disasters, we can claim, based on previous global experiences, that various vulnerabilities are caused by gender roles and gender-based inequalities, such as: lack of opportunities, lack of resources and more limited mobility of women than of men of the same social categories. Even in 141 countries it has been discovered that more women than men lose their lives in natural disasters ${ }^{6}$ (Making Disaster Risk Reduction Gender-Sensitive, 2009: 35) and that this phenomenon is associated with unequal socio-economic status of women ${ }^{7}$ (Neumayer and Plümper, 2007: 552).

Essentially, women have limited access to information and knowledge, which inevitably increases their vulnerability in risky situations. Poverty and marginalisation are associated

${ }^{5}$ We are fully aware that women comprise $70 \%$ of the world's poor and that women are more vulnerable to the impacts of disasters due to existing socio-economic, political and cultural disadvantages.

6 A recent study of 141 countries found that more women than men die from natural hazards, and that this disparity is linked most strongly to women's unequal socio-economic status.

${ }^{7}$ Looking at the effects of natural disasters in 141 countries over the period 1981 to 2002, the study shows that in societies where the socio-economic status of women is low, natural disasters kill more women than men, both directly and indirectly via related post-disaster events. The reason for the difference in mortality lies largely in the everyday socio-economic status of women. 
with a high degree of vulnerability to the impact of climate change, as well as reduced adaptability capabilities due to limited access to economic and non-economic resources, and information and support networks. Gender is the key variable in this context: unequal gender relations increase female vulnerability to the impact of climate change and reduce their adaptability (Jungehülsing, 2012). Consequently, the policies, instruments, mechanisms and tools used to respond to disasters and climate change cannot be neutral in relation to gender, and should not be formulated and applied without considering specific gender differences.

\section{DISASTER RISK REDUCTION: HYOGO AND SENDAI FRAMEWORK DOCUMENTS}

Increased appreciation of the need to integrate disaster risk reduction into development policies and activities was formalised in January 2005, when the Hyogo Framework for Action 2005-2015 was adopted by 168 countries and multilateral institutions ${ }^{8}$. The Hyogo Framework for Action states that the gender perspective should be integrated into all disaster risk management policies, planning and decision-making, including those related to risk assessment, early warning, information management, and education and training. The necessity of gender sensitive risk assessment was also noticed. A gender aspect always exists and must be identified: when determining the degree of exposure to natural phenomena, natural disasters or climate change; in the manner of analysing women and men in response to disasters, and the recovery from their consequences, and in building capacities to adapt to changes and create responses to them. This would result in gender sensitive planning of emergency management, which unites individuals in the responsibilities and actions to achieve the goal - a safe, gender equitable and economically developed local community.

Disaster Risk Reduction is a conceptual framework that addresses ways and methods for reducing vulnerability and risk of disasters in societies in order to avoid or hinder adverse impacts and dangers caused by natural phenomena and ensure sustainable development. It is a complex and multidisciplinary process involving the acceptance of international and legal obligations, public understanding, scientific knowledge, careful planning of development, responsible implementation of programme policies and laws, early warning systems, and effective mechanisms for emergency preparedness and response. Reducing disaster risk, also, requires collective involvement and engagement of national policymakers and government decision-makers, civil society, academic institutions, private sector and the media. Research shows the benefits of preventing or reducing the impact of a disaster - for every dollar invested in reducing disaster risks, two to four dollars can be saved, and they are needed for humanitarian aid, rehabilitation and reconstruction.

One of the key strategies of these efforts is, as foreseen by the Sendai Framework, a successor document to the Hyogo Framework, empowering women and persons with disabilities to publicly promote equitable and universally accessible reactions, recovery,

\footnotetext{
${ }^{8}$ Serbia is one of the signatory countries.
} 
rehabilitation and reconstruction. Disasters have shown that the recovery, rehabilitation and reconstruction phase is actually a starting point for planning and preparing prevention and response to future disasters. It is then necessary to develop such systems through a participatory process, to adapt them to the needs of users, including social and cultural requirements, especially those based on gender.

\section{CONCLUSION}

The consequences of the assumption that disaster risk is gender neutral is: incorrect identification and risk assessment, inadequately conceived policy response, policy making and risk financing at the national and community level. The starting point for reducing disaster risk and promoting a culture of disaster relief lies in the knowledge of the dangers of both physical, social, economic and environmental disaster vulnerabilities that most societies face. We should always bear in mind that disasters do not discriminate, but people do (UNISDR, UNDP and IUCN, 2009).

A gender-inclusive, non-discriminatory approach to reducing disaster risk can achieve a beneficial result for families and communities, as women, if given equal opportunities, can perform multiplied functions properly - as participants in all security-building processes, as well as leaders in disaster risk reduction. It is very important that a woman is not always seen as a victim, but in the whole process of disaster risk reduction she has an active role, both during and after the disaster (Centre for Disaster Preparedness, 2010.c). One of the lessons we have learnt from earlier disasters, which is always stated in the context of gender aspects, is that it is very important to involve expert women when recovery interventions are planned (UNISDR, 2007).

For this reason, laws, policies and practices should take into account the fact that, due to different economic, social, reproductive and political roles of men and women, they also have different capacities and needs in responding to the effects of disasters and climate change. Disaster risk reduction must be integrated into all policies, plans and programmes for sustainable development and poverty reduction, and supported through bilateral, regional and international cooperation, as well as through various types of partnership (Oxfam-GB, 2011). It is evident from previous practice that women taking on multiple roles on behalf of their communities are able not only to strengthen the capacity of their community to deal with catastrophes, but also to build active citizenship dealing with development priorities, which are inextricably linked to the reduction vulnerability. In doing so, resilience to disasters, community development and empowerment of women are elements of unique, but not separated, efforts (ISDR, 2007).

\section{REFERENCES:}

Bangladesh - Rebuilding Cyclone Sidr Victims. Retrieved on 21 September 2018 from $\mathrm{http}: / / \mathrm{www}$.youtube.com/watch? $=\mathrm{v}=\mathrm{Qj}$ ACB5k0Vk.

Begum, R. (1993). Women in environmental disasters: the 1991 cyclone in Bangladesh. Focus on Gender 1 (1), 34-39. Retrieved on 20 September 2018 from https://www.gdnonline.org/sourcebook/chapt/doc_view.php?id=7\&docid=776. 
Building Resilience to Natural Disasters: A Framework for Private Sector Engagement. World Economic Forum The World Bank, United Nations International Strategy for Risk Reduction. (January 2008). Retrieved on 10 June 2018 from http://www.unisdr.org/files/1392_DisastersRepFINCopyright.pdf.

Gender Perspective: Working Together for Disaster Risk Reduction, Good Practices and Lessons Learned. (June 2007). Geneva: United Nations ISDR.

Halvorson S. J. \& Hamilton J. P. (2005). The 2005 Kashmir Earthquake: A Perspe-ctive on Women's Experiences, Geography Faculty Publication 27 (4), 296-301.

Retrieved on 26 August 2018 from

https://scholarworks.umt.edu/cgi/viewcontent.cgi?article=1001\&context=geograp hy_pubs.

Handbook, Women Leadership in Disaster Risk Management. (2011). Bangladesh:

Oxfam-GB. Retrieved on 26 June 2018 from

http://www.preventionweb.net/files/submissions/19919_makeup2englishfinal.pdf.

History.com Editors, (2009). Bangladesh Cyclone of 1991. New York City: A\&E Television Networks. Retrieved on 19 September 2018 from http://www.history.com/topics/bangladesh-cyclone-of-1991.

Hyogo Framework for Action 2005-2015: Building the resilience of nations and communities to disaster, Mid-term Review 2010-2011. (March 2011). Geneva:

UNISDR. Retrieved on June 23, 2018 from

https://www.unisdr.org/files/18197_midterm.pdf.

Integrating Gender into Community Based Disaster Risk management: Training Manual. CBDRM Training and Learning Circle Philippines (2010). Retrieved on June 15, 2018 from http://library.pcw.gov.ph/sites/default/files/Integrating-Gender-intoCBDRM-Training-Manual.pdf.

Jungehülsing, J. (2012). Gender Relations and Women's Vulnerability to Climate Change, in Climate Change, Mexico City: Heinrich Boell Stiftung. Retrieved on 13 June 2018 from http://www.boell.de/downloads/2012-04-gender-climate-changetabasco.pdf.

Making Disaster Risk Reduction Gender-Sensitive, Policy and Practical Guidelines. (2009). Geneva: Published by UNISDR, UNDP and IUCN. pp. 24, 35, 44, 46 and 133. Retrieved on 8 June 2018 from https://www.unisdr.org/files/9922_MakingDisasterRiskReductionGenderSe.pdf.

Mathbor, M.G. (2016). Local Capacity Building in Humanitarian Crises: An Effective Dealing Strategy for Bangladesh. Sociology and Anthropology 4(5), 408-415.

Most tsunami dead female - Oxfam. (26. March 2005). BBC NEWS. Retrieved on 22 December 2012 from http://news.bbc.co.uk/2/hi/asia-pacific/4383573.stm.

Mršević Z., Janković S. (2018). Inkluzivna bezbednost kao način smanjenja rizika od katastrofa i pratećeg nasilja. U: Macanović, N. (2018). Ne nasilju, jedinstveni društveni odgovor. (str. 401 -411). Banja Luka: Centar modernih znanja.

Neumayer E., Plümper, T.( 2007). „The Gendered Nature of Natural Disasters: The Impact of Catastrophic Events on the Gender Gap in Life Expectancy“, Annals of the 
Association of American Geographers 97(3), 551-566. Retrieved on 21 July 2018 from http://gsdrc.org/document-library/the-gendered-nature-of-natural-disastersthe-impact-of-catastrophic-events-on-the-gender-gap-in-life-expectancy/

Singh D. (2012). IDDR 2012 - Putting women and girls on the map, Geneva: Published by UNISDR. Retrieved on 21 September 2018 from http://www.unisdr.org/archive/28886.

Žene i LGBT osobe nevidljive su žrtve katastrofa.(10. mart 2018). Zagreb: Libela portal. Retrieved on 8 July 2018 from https://www.libela.org/prozor-u-svijet/9386-zenei-lgbt-osobe-nevidljive-su-zrtve-katastrofa/.

The Hyogo Framework for Action 2005-2015: Building the resilience of nations and communities to disaster. (19 April 2008). Strasbourg: Council of Europe. Retrieved on 5 June 2018 from http://www.coe.int/t/dg4/majorhazards/ressources/Apcat2005/APCAT-2005-25Hyogo-frameworkISDR.pdf. 